\title{
HUBUNGAN POLA MAKAN KARBOHIDRAT, PROTEIN , LEMAK, DENGAN DIABETES MELLITUS PADA LANSIA
}

\author{
${ }^{1}$ Dwi Suprapti \\ ${ }^{1}$ STIKes Borneo Cendekia Medika Pangkalan Bun \\ Email : dwi.suprapti99@gmail.com
}

\begin{abstract}
ABSTRAK
Lanjut usia dapat dikatakan sebagai tahap akhir perkembangan pada daur kehidupan seorang manusia. Diabetes mellitus (DM) adalah salah satu jenis penyakit degeneratif yang mengalami peningkatan setiap tahun di seluruh dunia. Kejadian DM di Indonesia mengalami peningkatan, pada tahun 2007 sebesar $(5,7 \%)$ menjadi $(6,9 \%)$ pada tahun 2013. DM pada lansia di Indonesia merupakan masalah yang penting untuk dilakukan tindakan pencegahan dan pengendalian DM. Tujuan penelitian ini untuk menganalisis faktor hubungan pola makan karbohidrat, lemak, protein nabati, protein hewani dengan DM pada lansia terhadap risiko kejadian DM lansia. Jenis penelitian ini adalah kuantitatif dengan pendekatan cross sectional. Sampel dipilih secara purpossive berdasarkan kriteria usia 60-90 tahun, tidak memiliki komplikasi penyakit lain, masih mampu berkomunikasi dengan baik, bersedia menjadi responden, yakni sejumlah 165 subjek. Teknik pengumpulan data menggunakan angket atau wawancara. Analisis menggunakan univariat, bivariat menggunakan uji Chi-square dan multivariat menggunakan Regresi logistic sederhana dengan menggunakan program komputer. Distribusi frekuensi berdasarkan kejadian DM sebesar (53,3\%), pola makan karbohidrat sering ( $>3 x /$ hari) $(58,2 \%)$, pola makan lemak sering $(>3 x /$ hari) $(55,8 \%)$, pola makan protein hewani jarang $(<3 \mathrm{x} / \mathrm{hari})(53,9 \%)$, pola makan protein nabati jarang $(<3 x /$ hari) $(61,8 \%)$, umur lanjur $(52,1 \%)$, dan jenis kelamin perempuan $(67,3 \%)$. Hasil penelitian menunjukkan ada hubungan yang bermakna pola makan lemak dan umur dengan status diabetes mellitus. Pola makan karbohidrat menjadi variabel yang dominan dengan kejadian DM pada lansia (p-value 0.006, OR 2.250). Artinya pola makan karbohidrat sering $>3 \mathrm{x}$ /hari memiliki peluang risiko terkena DM sebanyak 2 kali lebih tinggi dibandingkan pola makan karbohidrat yang jarang $<3 x /$ hari. Sehingga lansia diharapkan agar dapat meningkatkan kesadaran terhadap kesehatan dirinya dengan cara melakukan pemeriksaan kadar gula darah setiap bulan, mengubah pola hidup yang kurang sehat menjadi pola hidup yang sehat, seperti mengatur pola makan yang seimbang dengan mengurangi konsumsi karbohidrat, lemak serta meningkatkan makanan yang banyak mengandung serat seperti: sayur sayuran, buah-buahan, biji-bijian dan kacang-kacangan. Untuk penderita DM yang baru terdiagnosis perlu secara rutin berkonsultasi pada ahli gizi agar program diet dapat terlaksana dengan baik, melakukan olahraga ringan, mengikuti promosi kesehatan mengenai diabetes mellitus yang diberikan oleh tenaga kesehatan, berobat rutin bagi lansia yang sudah terdiagnosa diabetes mellitus guna mengurangi risiko terkena diabetes mellitus.
\end{abstract}

Kata Kunci : Pola makan, aktivitas fisik, stres, lansia. 


\title{
THE RELATIONSHIP OF CARBID HYDRAULIC, PROTEIN, FAT, DIABETES MELLITUS DIABETES IN ELDERLY
}

\begin{abstract}
Old age can be said to be the final stage of development in a human's life cycle. Diabetes mellitus (DM) is a type of degenerative disease that has increased every year throughout the world. The incidence of DM in Indonesia has increased, in 2007 by $(5.7 \%)$ to $(6.9 \%)$ in 2013. DM in the elderly in Indonesia is an important issue for DM prevention and control. The purpose of this study was to analyze the relationship factors of carbohydrate, fat, vegetable protein, and animal protein diets with DM in the elderly to the risk of the incidence of elderly DM. This type of research is quantitative with a cross sectional approach. The sample was selected purposively based on the criteria of age 60-90 years, had no complications of other diseases, was still able to communicate well, was willing to be a respondent, ie a number of 165 subjects. Data collection techniques using questionnaires or interviews. Analysis using univariate, bivariate using Chi-square test and multivariate using simple logistic regression using a computer program. Frequency distribution based on DM incidence (53.3\%), frequent carbohydrate diet ( $>3 x /$ day) (58.2\%), frequent fat diet (> $3 x /$ day) $(55.8 \%)$, protein diet rare animal $(<3 x /$ day) $(53.9 \%)$, rare vegetable protein diet $(<3 x /$ day) (61.8\%), longevity (52.1\%), and female gender $(67.3 \%)$. The results showed a significant relationship between fat diet and age with diabetes mellitus status. Carbohydrate diet became the dominant variable with the incidence of DM in the elderly ( $p$-value 0.006, OR 2.250). This means that carbohydrate diets often> $3 x /$ day have a 2 times higher risk of developing DM compared to carbohydrate diets that are rarely $<3 x /$ day. So that the elderly are expected to be able to increase awareness of their health by checking blood sugar levels every month, changing unhealthy lifestyles into healthy lifestyles, such as regulating a balanced diet by reducing the consumption of carbohydrates, fats and increasing foods that contain lots of fiber such as: vegetables - fruits, grains and nuts. For newly diagnosed DM sufferers, it is necessary to routinely consult a nutritionist so that the diet program can be carried out well, doing light exercise, following health promotion regarding diabetes mellitus provided by health workers, regular treatment for the elderly who have been diagnosed with diabetes mellitus in order to reduce the risk of getting affected diabetes mellitus.
\end{abstract}

Keywords: Eating patterns, physical activity, stress, elderly.

\section{PENDAHULUAN}

Diabetes Mellitus yang umum dikenal sebagai kencing manis adalah penyakit yang ditandai dengan hiperglikemia (peningkatan kadar gula darah) yang terus-menerus dan bervariasi, terutama setelah makan [1]. Diabetes melllitus masuk sebagai salah satu penyakit degeneratif yang sering dijumpai pada usia lanjut dan mengalami peningkatan setiap tahun nya di negara-negara seluruh dunia. Menurut International of Diabetic Federation (IDF, 2015) tingkat prevalensi global penderita DM pada tahun 2014 sebesar $(8,3 \%)$ dari keseluruhan penduduk di dunia dan mengalami peningkatan pada tahun 
2015 menjadi 387 juta kasus. Data dari World Health Organization (WHO), sekitar 347 juta orang di seluruh dunia menderita diabetes, dan diperkirakan bahwa kematian akibat diabetes akan meningkat dua pertiga kali antara tahun 2008 dan 2030. Beban diabetes meningkat secara global, khusunya di negara berkembang [2].

Pada tahun 2011, Indonesia menempati urutan ke-10 jumlah penderita DM terbanyak di dunia dengan jumlah 7,3 juta orang dan jika hal ini berlanjut diperkirakan pada tahun 2030 penderita DM dapat mencapai 11,8 juta orang. Angka kejadian DM menurut data Riskesdas (2013) terjadi peningkatan dari 5,7\% di tahun 2007 meningkat menjadi 6,9\% di tahun 2013 dari keseluruhan penduduk sebanyak 250 juta jiwa. Prevalensi data penderita DM di Provinsi Jawa Tengah pada tahun 2014 mengalami peningkatan dari $14,96 \%$ menjadi $16,69 \%$ pada tahun 2015. Peningkatan prevalensi data penderita DM di atas yakni mencapai 152.075 kasus. Jumlah penderita DM tertinggi 5.919 jiwa di Kota Semarang (Profil Kesehatan Jawa Tengah, 2011). Data Depkes RI (2012) menunjukkan ratarata kasus penderita DM di Jawa Tengah sebanyak 4.216 kasus.

Diabetes mellitus di picu oleh faktor-faktor seperti kurang gerak, makan yang berlebihan, kehamilan, kekurangan produksi hormon insulin, dan penyakit hormon yang kerjanya berlawanan dengan insulin [3]. Gaya hidup perkotaan dengan pola diit yang tinggi lemak, garam, dan gula secara berlebihan mengakibatkan berbagai penyakit termasuk diabetes mellitus. Dan hampir $50 \%$ pasien diabetes mellitus berusia 65 tahun ke atas. Usia secara kronologis hanya merupakan suatu determinan dari perubahan yang berhubungan dengan penerapan terapi obat secara tepat pada orang lanjut usia. UU No. 13 tahun 1998 tentang kesehatan dikatakan bahwa usia lanjut adalah seseorang yang telah mencapai usia 60 tahun ke atas [4 ]. Menurut UU No. 4 tahun 1995 lansia adalah seseorang yang telah mencapai usia 55 tahun, tidak berdaya mencari nafkah sendiri untuk keperluan hidupnya sehari-hari dan menerima nafkah dari orang lain maupun dari keluarga.

Hasil survei dari Dinas Kesehatan Kota Pangkalan Bun tahun 2014 terdapat jumlah penderita Diabetes Mellitus usia 50-70 tahun sejumlah 2.147 lansia diabetes mellitus, total jumlah lansia di puskesmas Semanggang sejumlah 3.461 lansia sehat maupun yang sakit, sedangkan lansia yang menderita penyakit diabetes mellitus di wilayah kerja Puskesmas Semanggang sejumlah 214 lansia. Berdasarkan survei awal pada tanggal 28 September 2016 di Puskesmas Semanggang terdapat 6 dari 10 pasien lansia positif diabetes mellitus, dan selanjutnya perlu diteliti faktor-faktor yang berhubungan dengan kejadian diabetes mellitus pada lansia.

\section{METODE PENELITIAN}

Penelitian ini merupakan penelitian kuantitatif dengan desain cross sectional. Penelitian ini dilakukan di Wilayah kerja Puskesmas Semanggang. Populasi nya adalah seluruh lansia yang di Puskesmas Semanggang dengan kriteria usia 6090 tahun, tidak memiliki komplikasi penyakit lain, masih mampu berkomunikasi dengan baik, dan sampel berjumlah 165 responden. Tehnik pengumpulan data menggunakan kuesioner FFQ (Food Frequency Questionnaire), dengan menanyakan dan mencatat jenis 
makanan apa saja yang terakhir di konsumsi satu minggu yang lalu oleh responden serta seberapa sering frekuensi nya. Di beri kode 0 dengan kategori sering jika frekuensi $>3 \mathrm{x} /$ hari, dan kode 1 dengan kategori jarang jika frekuensi $<3 x /$ hari.

Data diambil oleh peneliti dan dibantu oleh perawat dan kader posyandu lansia Wilayah Kerja Puskesmas Semanggang. Data dan informasi yang terkumpul dianalisis secara bertahap menggunakan univariat, bivariat (Chi square) dan multivariat (regresi logistic sederhana).

\section{HASIL}

1. Analisis Univariat

\begin{tabular}{|c|c|c|}
\hline Variabel & Frekuensi (n) & Persentase (\%) \\
\hline \multicolumn{3}{|l|}{ Diabetes Mellitus } \\
\hline Tidak & 87 & $46.7 \%$ \\
\hline Ya & 88 & $53.3 \%$ \\
\hline \multicolumn{3}{|c|}{ Pola Makan Karbohidrat } \\
\hline Jarang $<3 \mathbf{x} /$ hari & 69 & $41.8 \%$ \\
\hline Sering $>3 \mathbf{3 x} /$ hari & 96 & $58.2 \%$ \\
\hline \multicolumn{3}{|l|}{ Pola Makan Lemak } \\
\hline Jarang $<3 \mathbf{x} /$ hari & 73 & $44.2 \%$ \\
\hline Sering $>3 x /$ hari & 92 & $55.8 \%$ \\
\hline \multicolumn{3}{|c|}{ Pola Makan Protein (H) } \\
\hline Jarang $<\mathbf{3 x} /$ hari & 89 & $53.9 \%$ \\
\hline Sering > 3x/hari & 76 & $46.1 \%$ \\
\hline \multicolumn{3}{|c|}{ Pola Makan Protein (N) } \\
\hline Jarang $<3 \mathbf{x} /$ hari & 102 & $61.8 \%$ \\
\hline Sering $>3 \mathbf{3 x} /$ hari & 63 & $38.2 \%$ \\
\hline \multicolumn{3}{|l|}{ Umur } \\
\hline Lanjut (60-75th) & 86 & $52.1 \%$ \\
\hline Tua (76-90th) & 79 & $47.9 \%$ \\
\hline \multicolumn{3}{|l|}{ Jenis Kelamin } \\
\hline Perempuan & 111 & $67.3 \%$ \\
\hline
\end{tabular}

Sebagian besar yang DM sebesar $(53.3 \%)$, pola makan karbohidrat sering $>3 x$ /hari $(58.2 \%)$, pola makan lemak sering $>3 \mathrm{x} /$ hari $(55.8 \%)$, pola makan protein hewani jarang $<3 \mathrm{x} /$ hari sebesar $(53.9 \%)$, pola

makan protein nabati jarang $<3 x /$ hari $(61.8 \%)$, umur lanjut sebesar

Hasil analisis pada tabel 3 hubungan pola makan lemak dengan kejadian diabetes mellitus didapatkan nilai hitung Odss ratio (OR) sebesar 2.445 dengan nilai $\mathrm{p}=0.005 ; \mathrm{CI}(95 \%)=$ 1.303-4.590. Persentase pola makan lemak jarang sebesa (44.3\%) dan pola makan lemak sering sebesar $(55.7 \%)$, beda proporsinya sebesar (11.4\%).
$(52,1 \%)$, dan jenis kelamin perempuan sebesar $(67,3 \%)$.

2. Analisis Bivariat

\begin{tabular}{|c|c|c|c|c|c|c|c|}
\hline \multicolumn{4}{|c|}{ Status DM } & \multicolumn{4}{|c|}{$\mathrm{CI}(95 \%)$} \\
\hline $\begin{array}{c}\text { Pola } \\
\text { Makan KH }\end{array}$ & Ya (\%) & Tidak (\%) & $\begin{array}{c}\text { Total } \\
(\%)\end{array}$ & OR & $\begin{array}{l}\text { Batas } \\
\text { Bawah }\end{array}$ & $\begin{array}{c}\text { Batas } \\
\text { Atas }\end{array}$ & $\begin{array}{c}p- \\
\text { value }\end{array}$ \\
\hline $\begin{array}{l}\text { Jarang } \\
<3 \mathrm{x} / \mathrm{hari}\end{array}$ & $20(29.0 \%)$ & $49(71.0 \%)$ & $69(41.8 \%)$ & & & & \\
\hline $\begin{array}{l}\text { Sering } \\
>3 \mathrm{x} / \text { hari }\end{array}$ & $68(70.8 \%)$ & $28(29.2 \%)$ & $96(58.2 \%)$ & 5.950 & 3.010 & 11.769 & 0.001 \\
\hline Total & $88(53.3 \%)$ & $77(46.7 \%)$ & $165(100 \%)$ & & & & \\
\hline
\end{tabular}

Hasil analisis pada tabel 2 hubungan pola makan karbohidrat dengan kejadian diabetes mellitus didapatkan nilai hitung Odss ratio (OR) sebesar 5.950 dengan nilai $\mathrm{p}=0.001$; $\mathrm{CI}(95 \%)=3.010-11.769$. Persentase pola makan karbohidrat jarang sebesar $(41.8 \%)$ dan pola makan karbohidrat sering sebesar (58.2\%), beda proporsinya sebesar $(16.4 \%)$. Lansia yang memiliki pola makan karbohdirat sering $>3 x /$ hari memiliki peluang risiko terkena diabetes mellitus 6 kali lebih tinggi dibandingkan dengan lansia yang memiliki pola makan karbohidrat jarang $<3 x /$ hari. Hal ini menunjukkan terdapat hubungan yang signifikan pola makan karbohidrat dengan kejadian diabetes mellitus.



Lansia yang memiliki pola makan lemak sering $>3 x /$ hari memiliki peluang risiko terkena diabetes mellitus 2 kali lebih tinggi dibandingkan dengan lansia yang memiliki pola makan lemak jarang $<3 x /$ hari. Hal ini menunjukkan terdapat hubungan yang signifikan pola makan lemak dengan kejadian diabetes mellitus. 


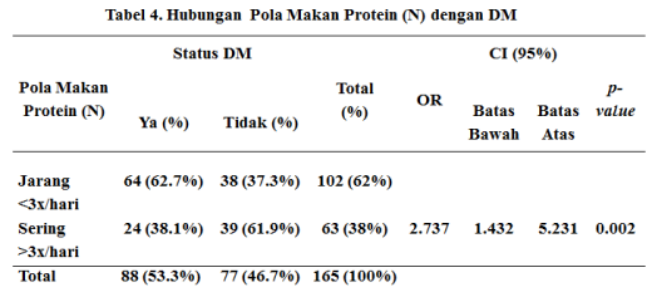

Hasil analisis pada tabel 4 hubungan pola makan protein nabati dengan kejadian diabetes mellitus didapatkan nilai hitung Odss ratio (OR) sebesar 2.737 dengan nilai $\mathrm{p}=0.002 ; \mathrm{CI}(95 \%)=1.432-5.231$. Persentase pola makan protein nabati jarang sebesar (62\%) dan pola makan protein nabati sering sebesar (38\%), beda proporsinya sebesar (24\%). Lansia yang memiliki pola makan protein nabati jarang $<3 x /$ hari memiliki peluang risiko terkena diabetes mellitus 3 kali lebih tinggi dibandingkan dengan lansia yang memiliki pola makan protein nabati sering $>3 x /$ hari. Hal ini menunjukkan terdapat hubungan yang signifikan pola makan protein nabati dengan kejadian diabetes mellitus.

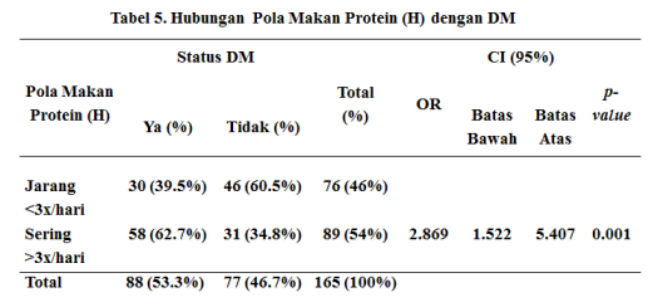

Hasil analisis pada tabel 5 hubungan pola makan protein hewani dengan kejadian diabetes mellitus didapatkan nilai hitung Odss ratio (OR) sebesar 2.869 dengan nilai $\mathrm{p}=0.001 ; \mathrm{CI}(95 \%)=1.522-5.407$. Persentase pola makan protein hewani jarang sebesar (46\%) dan pola makan protein hewani sering sebesar (54\%), beda proporsinya sebesar $(8 \%)$. Lansia yang memiliki pola makan protein hewani sering $>3 x$ /hari memiliki peluang risiko terkena diabetes mellitus 3 kali lebih tinggi dibandingkan dengan lansia yang memiliki pola makan protein hewani jarang <3x/hari. Hal ini menunjukkan terdapat hubungan yang signifikan pola makan protein hewani dengan kejadian diabetes mellitus.

\begin{tabular}{|c|c|c|c|c|c|c|c|}
\hline \multirow[b]{2}{*}{ Umur } & \multicolumn{2}{|c|}{ Status DM } & \multirow[b]{2}{*}{$\begin{array}{l}\text { Total } \\
(\%)\end{array}$} & \multirow[b]{2}{*}{ OR } & \multicolumn{2}{|c|}{$\mathrm{CI}(95 \%)$} & \multirow[b]{2}{*}{$\begin{array}{c}p- \\
\text { value }\end{array}$} \\
\hline & Ya (\%) & Tidak (\%) & & & $\begin{array}{l}\text { Batas } \\
\text { Bawah }\end{array}$ & $\begin{array}{l}\text { Batas } \\
\text { Atas }\end{array}$ & \\
\hline $\begin{array}{l}\text { Lanjut (60- } \\
75 \text { th) }\end{array}$ & $53(61.6 \%)$ & $33(38.4 \%)$ & $86(52 \%)$ & & & & \\
\hline $\begin{array}{l}\text { Tua (76- } \\
\text { 90th) }\end{array}$ & $35(44.3 \%)$ & $44(55.7 \%)$ & $79(\mathbf{4 8 \%} \%)$ & 2.019 & 1.085 & 3.758 & 0.026 \\
\hline
\end{tabular}

Hasil analisis pada tabel 6 hubungan umur dengan kejadian diabetes mellitus, didapatkan nilai hitung Odss ratio (OR) sebesar 2.019 dengan nilai $\mathrm{p}=0.026$; $\mathrm{CI}(95 \%)=$ 1.085-3.758. Persentase umur lanjut (60-75th) sebesar (52\%) dan umur tua (76-90th) sebesar (48\%), beda proporsinya sebesar (4\%). Lansia usia lanjut (60-75th) memiliki peluang risiko terkena diabetes mellitus 2 kali lebih tinggi dibandingkan dengan lansia usia tua (76-90). Hal ini menunjukkan terdapat hubungan yang signifikan antara umur dengan kejadia diabetes mellitus.

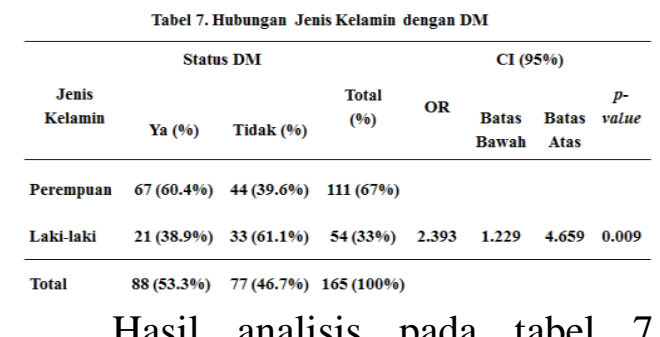
hubungan jenis kelamin dengan kejadian diabetes mellitus, didapatkan nilai hitung Odss ratio (OR) sebesar 2.393 dengan nilai $\mathrm{p}=0.009 ; \mathrm{CI}(95 \%)=$ 1.229-4.659. Persentase kelamin perempuan sebesar (67\%) dan jenis kelamin laki-laki sebesar (33\%), beda proporsinya sebesar (34\%). Lansia yang berjenis kelamin perempuan memiliki peluang risiko terkena diabetes mellitus 2 kali lebih tinggi dibandingkan dengan lansia yang 
berjenis kelamin laki-laki. Hal ini menunjukkan terdapat hubungan yang signifikan antara umur dengan kejadia diabetes mellitus.

\begin{tabular}{lcc}
\multicolumn{3}{c}{ Tabel 8. Akhir Multivariat } \\
\hline Variabel & p-value & OR \\
\hline Pola Makan KH & 0.004 & 2.250 \\
Pola Makan Lemak & 0.007 & 2.116 \\
Pola Makan Protein (H) & 0.413 & 1.341 \\
Umur & 0.020 & 2.211 \\
Jenis Kelamin & 0.013 & 2.241 \\
\hline
\end{tabular}

Hasil analisis pada tabel 8 akhir multivariat diketahui nilai OR paling tinggi yaitu terdapat pada variabel karbohidrat, maka faktor dominan dari kejadian diabetes mellitus adalah pola makan karbohidrat setelah di kontrol oleh variab

el jenis kelamin. Variabel pola makan protein hewani merupakan variabel confounding karena p-value $>0.005$. Kemudian dari hasil analisis multivariat diperoleh variabel yang berhubungan dan bermakna dengan status diabetes mellitus adalah variabel pola makan lemak dan umur. Hasil analisis didapatkan OR paling tinggi pada variabel pola makan karbohidrat 2.250 artinya pola makan karbohidrat sering $>3 \mathrm{x} /$ hari memiliki peluang risiko terkena DM sebanyak 2 kali lebih tinggi dibandingkan pola makan karbohidrat yang jarang $<3 \mathrm{x} /$ hari.

\section{PEMBAHASAN}

\section{Hubungan pola makan karbohidrat} dengan Kejadian DM Pada Lansia

Sebagian besar lansia dengan frekuensi pola makan karbohidrat sering $(>3 \mathrm{x} /$ hari) dengan DM yaitu sebesar (70,8\%), nasi adalah jenis makanan pokok yang persentase nya paling tinggi di konsumsi oleh responden sebanyak $148 \quad(89,7 \%)$ dengan frekuensi terbanyak adalah $>3 \mathrm{x} /$ hari sebanyak 112 responden (68\%). Dalam satu centong nasi (100 g) URT terdapat $(27,9 \mathrm{~g})$ karbohidrat dengan indeks glikemik 86 tergolong makanan yang memiliki indeks glikemik tinggi, semakin sering responden mengkonsumsi makanan yang memiliki indeks glikemik tinggi, dapat mengakibatkan kenaikkan kadar gula dalam darah secara cepat.

Hasil secara statistik menunjukkan adanya hubungan antara pola makan dengan kejadian DM pada lansia dengan $p$-value sebesar 0.001 ( $p$ value $<0.005$ ), dengan nilai $\mathrm{OR}=$ 5.950. Artinya lansia yang memiliki pola makan karbohidrat sering $>3 x /$ hari mempunyai peluang risiko 6 kali lebih tinggi untuk menderita diabetes mellitus dibanding dengan lansia yang memiliki pola makan karbohidrat jarang $<3 x / h a r i$. Hasil penelitian ini sesuai dengan hasil penelitian yang dilakukan oleh Schulze et al, (2004) yang menyatakan bahwa ada hubungan asupan karbohidrat dengan peningkatan kadar gula darah, sehingga menyebabkan timbulnya penyakit DM tipe II.

Asupan makanan merupakan faktor risiko yang diketahui dapat menyebabkan DM salah satunya asupan karbohidrat. Semakin berlebihan asupan makanan, besar kemungkinan terjangkitnya DM tipe II. Mekanisme hubungan asupan karbohidrat dengan kejadian DM tipe II dimana Karbohidrat akan dipecah dan diserap dalam bentuk monosakarida, terutama gula. Penyerapan gula menyebabkan peningkatan kadar gula darah dan meningkatkan sekresi insulin. Konsumsi karbohidrat yang berlebihan menyebabkan lebih banyak gula di dalam tubuh, pada penderita DM tipe II jaringan tubuh tidak mampu 
menyimpan dan menggunakan gula, sehingga kadar gula darah dipengaruhi oleh tingginya asupan karbohidrat yang dimakan. Pada penderita DM tipe II dengan asupan karbohidratnya tinggi melebihi kebutuhan, memiliki resiko 12 kali lebih besar untuk tidak dapat mengendalikan kadar glukosa darah dibandingkan dengan penderita yang memiliki asupan karbohidrat sesuai dengan kebutuhan [5].

\section{Hubungan pola makan lemak} dengan kejadian DM pada lansia

Sebagian besar lansia dengan frekuensi pola makan lemak sering (>3x/hari) dengan DM yaitu sebesar $(55,7 \%)$, dan jenis makanan cemilan/jajanan yang sering dikonsumsi oleh responden adalah donat sebanyak 65 responden $(39,39 \%)$ dengan frekuensi dua kali perminggu sebesar $(16,36 \%)$. Dalam satu buah donat diameter $5 \mathrm{~cm} \quad\left(\begin{array}{ll}100 & \mathrm{~g}\end{array}\right)$ mengandung $(61,12 \mathrm{~g})$ karbohidrat, $(10,33 \mathrm{~g})$ lemak, dan $(6,85 \mathrm{~g})$ protein, dengan indeks glikemik 76 tergolong pada makanan yang memiliki indeks glikemik tinggi . Jika tempat penyimpanan gula sudah penuh yakni otot atau hati, gula akan di simpan di dalam sel lemak dan di dalam sel lemak gula akan di ubah menjadi lemak [5]. Lemak merupakan sumber energi terbesar yang dapat menyebabkan obesitas. Pada orang yang obesitas sel sel lemak tersebut akan menghasilkan beberapa zat yang digolongkan sebagai adipositokin. Zat tersebut menyebabkan resistensi terhadap insulin. Akibat resistensi insulin, gula darah sulit masuk ke dalam sel sehingga gula di dalam darah tinggi atau hiperglikemi[6]. Pada penderita Diabetes mellitus terjadinya resistensi insulin yang menyebabkan peningkatan kadar glukosa darah, tekanan darah, hiperinsulinemia dan ketidaknormalan fungsi lemak yang di tandai dengan adanya peningkatan kadar kolesterol darah, LDL dan penurunan HDL ataupun peningkatan kadar trigliserida dalam darah yang merupakan faktor independen terhadap penyakit jantung [7].

Hasil secara statistik menunjukkan hubungan yang signifikan pola makan lemak dengan kejadian diabetes mellitus. Dengan nilai $\mathrm{p}=0,005$ dan Odss ratio (OR) sebesar 2.445,Lansia yang memiliki pola makan lemak sering $>3 x /$ hari memiliki peluang risiko terkena diabetes mellitus 2 kali lebih tinggi dibandingkan dengan lansia yang memiliki pola makan lemak jarang $<3 x /$ hari. Dan hal ini tidak sejalan dengan penelitian yang dilakukan oleh Diah Ayu Apritasari Mahendri tentang hubungan antara konsumsi karbohidrat dan kolesterol terhadap kadar glukosa darah pada penderita diabetes mellitus tipe II rawat jalan di RSUD Dr. Moewardi menyatakan bahwa tidak ada hubungan antara konsumsi karbohidrat dengan kadar glukosa darah GDP dan GD2JPP dan tidak ada hubungan antara konsumsi kolesterol dengan kadar glukosa darah GDP tetapi ada hubungan antara konsumsi kolesterol dengan kadar glukosa darah GD2JPP.

Konsumsi lemak dalam makanan berguna untuk memenuhi kebutuhan energi, membantu penyerapan vitamin A, D, E dan K serta menambah lezatnya makanan [8]. Perbanyak konsumsi makanan yang mengandung lemak tidak jenuh, baik tunggal maupun rangkap dan hindari konsumsi lemak jenuh. Asupan lemak berlebih merupakan salah satu penyebab terjadinya resistensi insulin dan kelebihan berat badan. Oleh karena itu, hindari pula makanan yang digoreng atau banyak mengggunakan minyak. Lemak tidak jenuh tunggal 
(monounsaturated) yaitu lemak yang banyak terdapat pada minyak zaitun, buah avokad dan kacang-kacangan. Lemak ini sangat baik untuk penderita DM karena dapat meningkatkan HDL dan menghalangi oksidasi LDL. Lemak tidak jenuh ganda (polyunsaturated) banyak terdapat pada telur, lemak ikan salem dan tuna [8].

\section{Hubungan pola makan protein nabati dengan kejadian diabetes mellitus}

Sebagian besar lansia dengan frekuensi pola makan protein nabati jarang $(<3 \mathrm{x} /$ hari) dengan DM sebesar (62,7\%). Makanan sumber protein dibagi menjadi dua, yaitu sumber protein nabati dan sumber protein hewani. Protein nabati adalah protein yang didapatkan dari sumber - sumber nabati. Sumber protein nabati yang baik dianjurkan untuk dikonsumsi adalah dari kacang - kacangan, di antaranya adalah kacang kedelai (termasuk produk olahannya, seperti tempe, tahu, susu kedelai dan lainlain), kacang hijau, kacang tanah, kacang merah dan kacang polong [9].

Selain berperan membangun dan memperbaiki sel-sel yang sudah rusak, konsumsi protein juga dapat mengurangi atau menunda rasa lapar sehingga dapat menghindarkan penderita diabetes dari kebiasaan makan yang berlebihan yang memicu timbulnya kegemukan. Makanan yang berprotein tinggi dan rendah lemak dapat ditemukan pada ikan, daging ayam bagian paha dan sayap tanpa kulit, daging merah bagian paha dan kaki, serta putih telur [9].

Sumber protein nabati yang paling sering dikonsumsi dan memiliki persentase paling tinggi adalah tempe sebanyak 105 responden $(63,7 \%)$ dengan frekuensi tiga kali sehari sebesar (45,5\%). Hal ini dikarenakan tempe mudah didapat dan harganya terjangkau oleh seluruh lapisan masyarakat. Dalam satu potong tempe URT (25 g) mengandung (3,2 g) karbohidrat, protein $(20,8 \mathrm{~g})$, dan lemak (8,8 g). Menurut Suyono (2007), berkurangnya aktivitas insulin pada diabetes dapat menghambat sintesis protein. Hasil secara statistik menunjukkan ada hubungan antara pola makan protein nabati dengan kejadian DM dengan p-value 0,002 dan OR 2.737. Artinya lansia yang mengonsumsi protein nabati jarang ( $<3 x /$ hari) memiliki risiko 3 kali lebih tinggi dibandingkan dengan lansia yang mengonsumsi protein nabati sering ( $>3 x /$ hari). Penelitian ini tidak sejalan dengan penelitian yang dilakukan oleh Kunthi Wandansari (2013) tentang hubungan pola makan dengan dan aktivitas fisik dengan kejadian diabetes mellitus di RSUD Dr. Moewardi Surakarta, mengatakan bahwa tidak ada hubungan antara pola makan mengonsumsi karbohdirat, konsumsi protein hewani, konsumsi protein nabati, konsumsi buah-buahan, konsumsi makanan jajanan, konsumsi fast food dengan kejadian DM tipe 2 sedangkan yang berhubungan dengan kejadian DM adalah variabel aktivitas fisik. Protein merupakan sumber asam amino yang dibutuhkan tubuh untuk proses pertumbuhan serta sumber energi bersama karbohidrat dan lemak. Protein terdiri dari 2 jenis yaitu protein hewani dan protein nabati. Protein nabati adalah protein yang didapatkan dari sumber-sumber nabati. Sumber protein nabati yang baik dianjurkan untuk dikonsumsi adalah dari kacangkacangan, di antaranya adalah kacang kedelai (termasuk produk olahannya, seperti tempe, tahu, susu kedelai dan lainlain), kacang hijau, kacang tanah, kacang merah dan kacang polong [9]. 
Pada masyarakat Indonesia sumber utama protein berasal dari jenis nabati yang bersumber pada beberapa kacang-kacangan karena mudah didapat dan harganya relatif murah. Fungsi utama protein adalah untuk pertumbuhan dan mengganti sel-sel yang rusak. Protein akan digunakan sebagai sumber energi apabila ketersediaan energi dari sumber lain yaitu karbohidrat dan lemak tidak mencukupi melalui proses glikoneogenesis. Hal tersebut sesuai dengan yang dikemukakan oleh Almatsier (2003) dan Djojosoebagio (1996) bahwa pencernaan protein menghasilkan asam amino dan sebagian besar asam amino digunakan untuk pembangunan protein tubuh. Bila tidak tersedia cukup karbohidrat dan lemak untuk kebutuhan energi maka sebagian dari asam amino dipecah melalui jalur yang sama dengan glukosa untuk menghasilkan energi. Hal tersebut juga dikemukakan oleh: Asdie (2000) bahwa pada pengidap diabetes yang tidak terkendali protein tubuh akan dipecah menjadi asam amino yang akan digunakan sebagai substrat untuk proses glikoneogenesis sehingga kadar glukosa darah pengidap diabetes semakin meningkat. Almatsier (2003), protein dalam jumlah yang berlebihan akan diubah menjadi lemak dan disimpan dalam tubuh yang juga akan menjadi substrat untuk proses glikoneogenesis.

\section{Hubungan pola makan protein hewani dengan kejadian diabetes mellitus}

Sebagian besar lansia dengan frekuensi pola makan protein hewani (>3x/hari) dengan DM sebesar $(62,7 \%)$. Sumber protein hewani yang paling sering dikonsumsi dan memiliki persentase paling tinggi adalah telur ayam sebanyak 103 responden
$(62,42 \%)$ dengan frekuensi empat kali perminggu sebesar $(27,3 \%)$. Hal ini dikarenakan responden merasa terlalu mahal jika membeli daging sapi maupun ayam, sebagai gantinya maka responden mengonsumsi telur ayam. Dalam satu butir telur ayam terdapat $(0,77 \mathrm{~g})$ karbohidrat, lemak $(9,94 \mathrm{~g})$, dan (12,58 g) protein [6]. Asupan protein sebesar $0,8 \mathrm{~g} / \mathrm{kg}$ BB ideal dapat mempertahankan protogenesis, dengan catatan $50 \%$ daripadanya harus berasal dari protein hewani.

Hasil secara statistik menunjukkan adanya hubungan antara pola makan protein hewani dengan kejadian DM pada lansia dengan $p$ value sebesar 0.001 ( $p$-value $<0.005$ ), dengan nilai $\mathrm{OR}=2.869$. Artinya lansia yang memiliki pola makan protein hewani sering $>3 x /$ hari mempunyai peluang risiko 3 kali lebih tinggi untuk menderita diabetes mellitus dibanding dengan lansia yang memiliki pola makan protein hewani jarang <3x/hari. Hal ini tidak sejalan dengan hasil penelitian Tri Lasmawati (2013) tentang hubungan asupan energy, protein dan zinc terhadap kadar gula darah pasien DM Tipe 2 di Klub Persadia RSU Santo Antonius Kota Pontianak menyatakan bahwa tidak ada hubungan antara asupan energy, protein dan zinc terhadap kadar gula darah pasien DM Tipe 2 di Klub Persadia RSU Santo Antonius Kota Pontianak.

Selain berperan membangun dan memperbaiki sel-sel yang sudah rusak, konsumsi protein juga dapat mengurangi atau menunda rasa lapar sehingga dapat menghindarkan penderita diabetes dari kebiasaan makan yang berlebihan yang memicu timbulnya kegemukan. Makanan yang berprotein tinggi dan rendah lemak dapat ditemukan pada ikan, daging ayam bagian paha dan sayap tanpa 
kulit, daging merah bagian paha dan kaki, serta putih telur [9].

\section{Hubungan Umur dengan Kejadian DM pada Lansia}

Sebagian besar umur lansia dengan DM adalah pada umur lanjut (60-90 tahun) yaitu sebesar 61,6\% . Hasil penelitian menunjukkan hubungan umur yang secara statistik signifikan antara umur lansia dan risiko lansia untuk mengalami Diabetes Mellitus dengan p-value 0.026 dan nilai Odds Ratio 2.019. Lansia yang memiliki umur lanjut akan mudah untuk terkena DM sebanyak 2 kali lebih tinggi daripada lansia yang memiliki umur tua. Hal ini sejalan dengan penelitian yang dilakukan oleh Dita Garnita (2012) tentang faktor risiko diabetes mellitus di Indonesia (Analisis Data Sakerti 2007), yang menyatakan bahwa terdapat hubungan yang signifikan antara setiap kategori umur dengan kejadian Diabetes Mellitus, dan kelompok umur yang mempunyai risiko terbesar untuk mengalami diabetes adalah diatas usia 50 keatas.

\section{Hubungan Jenis Kelamin dengan Kejadian DM pada Lansia}

Sebagian besar jenis kelamin lansia dengan DM adalah lansia dengan jenis kelamin perempuan yaitu sebesar $60,4 \%$. Hasil penelitian menunjukkan ada hubungan dan secara statistik signifikan antara jenis kelamin dengan risiko lansia untuk mengalami Diabetes Mellitus dengan $p$-value 0.009 dan nilai Odds Ratio 2,393. Lansia yang berjenis kelamin perempuan akan mengalami DM 2.393 kali lebih tinggi daripada lansia yang berjenis kelamin laki-laki. Hal ini sejalan dengan hasil Riset Kesehatan Dasar 2007 menunjukkan bahwa prevalensi TGT dan DM menurut pemeriksaan gula darah perempuan lebih tinggi dibandingkan dengan laki-laki. Prevalensi TGT pada perempuan adalah 11,5 \% (dibandingkan dengan $8,7 \%$ pada lakilaki), sedangkan prevalensi DM pada perempuan adalah $6,4 \%$ (dibandingkan dengan 4,9\% pada laki-laki).

Secara prevalensi, wanita dan pria mempunyai peluang yang sama terkena diabetes. Hanya saja, dari faktor risiko, wanita lebih berisiko mengidap diabetes karena secara fisik wanita memiliki peluang peningkatan indeks masa tubuh yang lebih besar. Sindroma siklus bulanan (premenstrual syndrome), pasca-menopouse yang membuat distribusi lemak tubuh menjadi mudah terakumulasi akibat proses hormonal tersebut sehingga wanita berisiko menderita diabetes melitus tipe 2. Selain itu pada wanita yang sedang hamil terjadi ketidakseimbangan hormonal progesteron tinggi, sehingga meningkatkan sistem kerja tubuh untuk merangsang sel-sel berkembang (termasuk pada janin), tubuh akan memberikan sinyal lapar dan pada puncaknya menyebabkan sistem metabolisme tubuh tidak bisa menerima langsung asupan kalori dan menggunakannya secara total sehingga terjadi peningkatan kadar gula darah saat kehamilan [10].

\section{KESIMPULAN DAN SARAN}

Terdapat hubungan yang
bermakna antara pola makan karbohidrat, pola makan lemak, pola makan protein nabati, pola makan protein hewani, umur dan jenis kelamin denga kejadian diabetes mellitus pada lansia. Bagi lansia diharapkan agar dapat meningkatkan kesadaran terhadap kesehatan dirinya dengan cara melakukan pemeriksaan kadar gula darah setiap bulan serta, mengubah pola hidup yang kurang sehat menjadi pola hidup yang lebih baik dan sehat, 
seperti mengatur pola makan yang seimbang dengan mengurangi konsumsi karbohidrat serta meningkatkan makanan yang banyak mengandung serat seperti: sayur sayuran, buah-buahan, biji-bijian dan kacang-kacangan. Untuk penderita DM yang baru terdiagnosis perlu secara rutin berkonsultasi pada ahli gizi agar program diet dapat terlaksana dengan baik, sehingga kadar gula darah dapat dikendalikan. Serta melakukan olahraga ringan, mengikuti promosi kesehatan mengenai diabetes mellitus yang diberikan oleh tenaga kesehatan, dan berobat rutin bagi lansia yang sudah terdiagnosa diabetes mellitus guna mengurangi risiko terkena diabetes mellitus.

\section{RUJUKAN}

Bilous R, dan Richard D. (2014). Buku Pegangan Diabetes Edisi Ke 4. Jakarta : Bumi Medika.

World Health Organization. (2011). Diabetes. Available From: http://www.who.int/mediacen tre/factsheets/fs312/en/index. html. [Accessed Desember 2016].

Brown, Judith E. et al. (2005). Nutrition Through the Life Cycle. ( $2^{\text {nd }}$ ed $)$ Wadsworth: USA.

Maryam, R. Siti, dkk. (2008). Mengenal Usia Lanjut dan Perawatannya. Jakarta: Salemba Medika.

Paruntu, Olga Lieke. 2012. Asupan Gizi dengan Pengendalian Diabetes Pada Diabetisi Tipe II Rawat Jalan di BLU Prof. Dr. R. D. Kandou Poltekkes Manado.

Kariadi, Sri Hartini KS. 2009. Diabetes ? Siapa Takut! Bandung: Penerbit Qanita.
ADA (American Diabetes Association) 2004. Diagnosis and Classification of DM. Diabetes Care, vol 27. Available from: http:// care. diabetesjournals. org/ content/ 27/suppl_1/s5.full.pdf+html[1 9 Februari 2016].

Andrani, dewi. (2014). Pengetahuan dan Motivasi Perawat dengan Keamanan Pemberian Terapi Obat. Diakses pada tanggal 24 February 2016.

Susanto, T. 2013. Diabetes deteksi, pencegahan, pengobatan. Buku pintar. Yogyakarta.

United States Departement of Agriculture (USDA), (2007). Nutrient Database for Standard Reference. RI.

Almatsier, S. (2005). Penuntun Diet Edisi Baru, Jakarta, PT Gramedia Pustaka Umum.

Almatsier, Sunita. 2003. Prinsip Dasar Ilmu Gizi. PT.Gramedia Pustaka Utama. Jakarta.

Damayanti, A. (2010). Prevalensi dan Faktor Risiko Kejadian Diabetes Melitus di Daerah Urban Indonesia. Jakarta : Tesis FKMUI.

Depkes RI. (2012), Profil Kesehatan Indonesia Tahun 2011. Jakarta : Departemen Kesehatan RI.

Dinkes Jateng. (2011). Profil Kesehatan Jawa Tengah. Semarang : Depkes Jateng.

DKK semarang (2014). Profil Kesehatan Kota Semarang 2013 Semarang; Dinas Kesehatan Kota Semarang.

Garnita, Dita.(2012). "Faktor Risiko Diabetes Melitus di Indonesia (Analisis Data Sakerti 2007)". Depok: Universitas Indonesia. International Diabetic Federation, (2015), IDF Diabetes Atlas, 
http://www.idf.org/atlasmap/a tlasmap, 03 Oktober 2016.

Balitbang Kemenkes RI. (2013). Riset

Kesehatan Dasar;

RISKESDAS. Jakarta:

Balitbang Kemenkes RI.

Balitbang Kemenkes RI. (2007). Riset

Kesehatan Dasar;

RISKESDAS. Jakarta:

Balitbang Kemenkes RI.

Supariasa. (2014). Penilaian Status

Gizi. Penerbit EGC. Jakarta.

Jiang R. Schulze MB, Rifai N, et al . (2004) Non-HDL Cholestrol and apolipoprotein B predict cariovasculer disease events among men with type 2 . diabetic care 2004; 1991-7.

Ayu, Dyah. (2015). Hubungan Antara

Konsumsi Karbohidrat dan

Kolesterol Terhadap Kadar

Glukosa Darah pada Penderita

Diabetes Melitus Tipe II

Rawat Jalan di RSUD Dr. Moewardi.

Wandansari, Kunthi. (2013). Hubungan pola makan dan aktivitas fisik dengan kejadian DM Tipe 2 di RSUD Dr. Moewardi Surakarta. Skripsi: Prodi kesehatan masyarakat fakultas ilmu kesehatan universitas muhammadiyah Surakarta.

Piliang, W.G dan S. Djojosoebagio. (1996). Fisiologi Nutrisi. Edisi Kedua. UI-Press. Jakarta Ahmad H.Asdie. (2000). Diagnosis dan klasifikasi diabetes melitus. Dalam : Patogenesis dan terapi diabetes melitus tipe 2 . Edisi 1. Yogyakarta : MEDIKA. Fakultas Kedokteran UGM. Hal : 1. 
